NBER WORKING PAPER SERIES

\title{
CAP AND TRADE POLICIES IN THE PRESENCE OF MONOPOLY AND DISTORTIONARY TAXATION
}

\author{
Don Fullerton \\ Gilbert E. Metcalf \\ Working Paper 8901 \\ http://www.nber.org/papers/w8901 \\ NATIONAL BUREAU OF ECONOMIC RESEARCH \\ 1050 Massachusetts Avenue \\ Cambridge, MA 02138 \\ April 2002
}

This research was supported by a grant to both authors from the National Science Foundation (NSF SBR9811324). The second author also acknowledges the support of the Joint Program on the Science and Policy of Global Change at MIT. Helpful comments were provided by Richard Arnott, Larry Goulder, Ian Parry, and Kerry Smith. David Fu provided excellent research assistance. This paper is part of the NBER's research program in Public Economics. The views expressed herein are those of the author and not necessarily those of the National Bureau of Economic Research.

(C) 2002 by Don Fullerton and Gilbert E. Metcalf. All rights reserved. Short sections of text, not to exceed two paragraphs, may be quoted without explicit permission provided that full credit, including $\odot$ notice, is given to the source. 
Cap and Trade Policies in the Presence of Monopoly and Distortionary Taxation Don Fullerton and Gilbert E. Metcalf

NBER Working Paper No. 8901

April 2002

JEL No. H2, Q2

\begin{abstract}
We extend an analytical general equilibrium model of environmental policy with pre-existing labor tax distortions to include pre-existing monopoly power as well. We show that the existence of monopoly power has two offsetting effects on welfare. First, the environmental policy reduces monopoly profits, and the negative effect on income increases labor supply in a way that partially offsets the pre-existing labor supply distortion. Second, environmental policy raises prices, so interaction with the pre-existing monopoly distortion further exacerbates the labor supply distortion. This second effect is larger, for reasonable parameter values, so the existence of monopoly reduces the welfare gain (or increases the loss) from environmental restrictions.
\end{abstract}

Don Fullerton

Department of Economics

University of Texas

Austin, TX 78712

and NBER

dfullert@eco.utexas.edu
Gilbert E. Metcalf

Department of Economics

Tufts University

Medford, MA 22105

and NBER

gmetcalf@tufts.edu 
The Clear Air Act of 1990 introduced cap and trade policies on a large scale for the electric utility industry in the United States. The goal of the tradable allowance program for sulfur dioxide $\left(\mathrm{SO}_{2}\right)$ emissions is to reduce emissions by 10 million tons below 1980 levels by 2008. ${ }^{1}$ That goal is to be met through a two-step phased reduction in emissions. Phase I ran from 1995 through 1999, and phase II began in 2000. Allowances are given to electric utilities on the basis of historic emissions. Giving away allowances, rather than selling them, was a political expedient that helped generate sufficient support for the allowances program that it could get off the ground. Economists have long noted the distributional implications of giving away allowances; more recently, economists have noted the efficiency implications of giving them away in the presence of pre-existing tax distortions. ${ }^{2}$ For example, Bovenberg and Goulder (1996) calculate that if marginal environmental damages (MED) from carbon emissions are only $\$ 25$ per ton, then the optimal carbon tax with revenues returned lump-sum is zero or negative (their Table 2, p. 992). In other words, no carbon tax is better than a positive carbon tax. Giving allowances to firms is conceptually equivalent to a carbon tax with revenues returned lump-sum, so their results suggest that sufficiently low environmental damages mean that the allowance program is welfare reducing. Parry (1997) also finds that pollution quotas can reduce welfare in the presence of pre-existing labor taxes. These papers assume perfectly competitive markets.

An important theoretical and empirical question is how the existence of market power affects the optimal design of environmental policy in the presence of distortionary taxation. In this paper, we extend a simple analytic general equilibrium model with environmental policy and pre-existing labor tax distortions to allow also for monopoly production of a polluting good. The electric generating industry has many characteristics of monopoly power. A recent report by the U.S. Department of Energy (Office of Policy (2000)) notes that many electricity markets are highly concentrated and that the restructuring of electricity markets raises the possibility of increased market power. The Wall Street Journal states: "Secretary of Energy Bill Richardson said he has 'strong evidence' that some utilities are using near-monopoly power to raise electric rates far beyond competitive levels" (Fialka (2000), p. A4). Yet much of the previous work in this area has assumed that firms are perfectly competitive.

In addition to extending the model, we provide numerical calculations of the impact of

\footnotetext{
${ }^{1}$ See Schmalensee et al. (1998) for a discussion of the characteristics of the emissions trading market. The program also put limits on nitrous oxide $\left(\mathrm{NO}_{\mathrm{x}}\right)$ emissions.
} 
pollution restrictions, both for a competitively-produced good and for a monopoly-produced good associated with pollution. An example of such a restriction on emissions is the introduction of permits under the Clean Air Act Amendments of 1990, but the model is general enough to represent different kinds of policies toward any pollutant in any country. Because all producers are identical in our model, a command and control (CAC) restriction on emissions is equivalent to a cap-and-trade permit policy. And because of perfect certainty, government capture of scarcity rents from either such quantity restriction is equivalent to a tax on pollution. Intermediate cases are also possible: handout of half the permits is equivalent to a pollution tax with half of the revenue returned lump sum.

Whereas Pigou (1932) proposes a tax on pollution equal to MED, Buchanan (1969) first notes that this prescription must be modified when the producer is a monopolist. Buchanan shows that the desired policy response in the case of a monopoly is to increase output, while the desired policy in the case of pollution is to decrease output. Thus, with a pollution-generating monopolist, one cannot tell a priori if a tax is desirable at all. Asch and Seneca (1976) identify conditions under which the imposition of a pollution tax equal to MED would increase or decrease welfare, again in the special case of linear demand and cost. In addition, they provide some data from the 1970s to show that a substantial number of industries have marked monopoly power and are significant sources of pollution. Misiolek (1980) extended Asch and Seneca's analysis by deriving the formula for the optimal tax rate on pollution for the special case of linear demand and cost. When the socially-efficient output is below the monopoly output, the optimal tax equals MED less a term equal to the ratio of MED to the price elasticity of demand. Barnett (1980) derives an optimal tax rule that does not impose linearity and also allows for pollution abatement activities. $^{3}$

All of these models are partial equilibrium and ignore the impact of pollution taxes on factor markets. They also ignore the possibility of pre-existing distortionary taxes in other markets. Browning (1994) shows that because monopoly power raises prices, it reduces the real net wage and exacerbates labor tax distortions. Then Browning (1997) shows that because taxes raise prices relative to the wage, they enlarge the welfare cost of monopoly. While Browning considers the interaction of monopoly power and taxes, other papers consider the interaction of

\footnotetext{
2 See e.g., Bovenberg and Goulder (1996), Parry (1997), Goulder et al. (1997), and Fullerton and Metcalf (2001).

3 Oates and Strassmann (1984) also calculate the welfare interactions of monopoly output restrictions and pollution. Their model is partial equilibrium in nature, however, and ignores other tax distortions.
} 
environmental policy and taxes (see Bovenberg and de Mooij (1994), Parry (1995), and other papers mentioned in footnote 2 above). Thus, a contribution of our paper is that we consider all three distortions simultaneously in a general equilibrium model that can be solved analytically. ${ }^{4}$

In prior competitive models where environmental policy generates scarcity rents (Fullerton and Metcalf (2001)), the extent of government capture of those rents affects whether environmental policy can improve welfare at all. ${ }^{5}$ However, that prior paper does not consider monopoly power, and it does not include any calculations, parameter values, or numerical magnitudes. Here, we find that the rate of profits tax (capture of rents) is equally important with monopoly power. However, the existence of monopoly has two offsetting effects on welfare. First, the environmental policy reduces monopoly profits. The resulting negative effect on income increases labor supply, which partially offsets the pre-existing labor supply distortion. Second, both monopoly and environmental policy raise prices and thus reduce the real net wage, so interaction between them exacerbates the labor supply distortion. Thus, adding monopoly power means adding an income effect that increases labor supply and a price effect (of higher output prices on the real net wage) that reduces labor supply. The relative magnitudes of these two offsetting effects can only be determined numerically. When we add parameter values and calculate the size of each effect, we find that this second effect is larger. For reasonable parameter values, the existence of monopoly reduces the welfare gain (or increases the loss) from environmental restrictions.

Next, we sketch out the general equilibrium model used in our analysis. Section I describes our initial model with perfectly competitive firms, while Section II provides some numerical results. Section III extends the model to allow for monopoly production of the dirty good, and Section IV concludes.

\section{The Model}

We develop a simple general equilibrium model with $\mathrm{N}$ identical individuals who own a

\footnotetext{
${ }^{4}$ Interest in environmental policy analysis under conditions of imperfect competition is growing as evidenced by Katsoulacos and Xepapadeas (1995) and the papers contained in Carraro et al. (1996). Nearly all these papers focus on oligopolistic markets in a partial equilibrium setting and ignore tax distortions in other markets.

5 The rents impact is related to the tax-interaction and revenue-recycling effects, as discussed by Goulder et al. (1997). We have avoided this terminology because the casual reader might confuse revenue recycling and revenue raising. See Fullerton and Metcalf (2001) for further discussion of this point.
} 
single resource and sell it in the market to earn income that can be used to buy two different goods. One of the goods is a "clean" good and the other is a "dirty" good (that is, one for which pollution is a by-product of the production process).

This static model considers only one time period, with no saving decision. For simplicity we refer to the resource as time available for labor supply, but under some conditions it can be interpreted more generally as a fixed total amount of labor, capital, land, and any other resource that can be sold in the market (in amount $\mathrm{L}$ ) or used at home (in amount $\mathrm{L}_{\mathrm{H}}$ ). The resource kept at home could be interpreted either as leisure or as a resource used in home production. We assume perfect certainty, no transactions costs, and constant returns to scale production.

Each individual receives utility from per-capita amounts of a nonpolluting good (X), a polluting good $(\mathrm{Y})$, and leisure $\left(\mathrm{L}_{\mathrm{H}}\right)$, and from the total amounts of a government-provided nonrival public good $(\mathrm{G})$, and another nonrival public good called environmental quality (E). The per-capita amount $\mathrm{Y}$ is produced using per-capita amounts of labor $\left(\mathrm{L}_{\mathrm{Y}}\right)$ and of emissions $(\mathrm{Z})$. Total emissions (NZ) negatively affect the environment through:

$$
\mathrm{E}=\mathrm{e}(\mathrm{NZ}), \quad \text { where } \mathrm{e}^{\prime}<0
$$

Goods are produced according to:

$$
\begin{gathered}
X=L_{X} \\
Y=F\left(L_{Y}, Z\right) \\
G=N_{G}
\end{gathered}
$$

We define a unit of $\mathrm{X}$ as the amount that can be produced using one unit of labor. The numeraire good is $\mathrm{L}$, or equivalently $\mathrm{X}$. The commodity $\mathrm{Y}$ is produced in a constant returns to scale function $(\mathrm{F})$, using clean labor $\left(\mathrm{L}_{Y}\right)$ and emissions $(\mathrm{Z})$. Emissions may include gaseous, liquid, or solid wastes and we assume that they require some private costs for removal and disposal. These private costs must come in the form of resources, so we define one unit of emissions as the amount that requires one unit of private resources $\left(\mathrm{Z}=\mathrm{L}_{\mathrm{Z}}\right){ }^{6}{ }^{6}$ Thus, the private

\footnotetext{
${ }^{6}$ Note that emissions are positively related to the use of these resources: $\mathrm{L}_{Z}$ is not to clean up or reduce emissions, but just to cart it away. Abatement is undertaken by substituting away from $Z$ and into $\mathrm{L}_{\mathrm{Y}}$. Marginal abatement cost in units of labor is given by the marginal rate of transformation between $\mathrm{L}_{Y}$ and $Z$. This overall production function is still constant returns to scale, since $Z$ is a linear function of $L_{Z}$. The private cost for emissions helps justify our assumption of an internal solution with a finite choice for $\mathrm{Z}$, even without corrective government policy.
} 
cost of $\mathrm{Z}$ is always 1 . We define a unit of $\mathrm{Y}$ such that the marginal cost of production equals 1 (before the introduction of environmental policy). Finally, some labor $\left(\mathrm{L}_{\mathrm{G}}\right)$ is also used to produce the public good. The combination of these production relationships provides the overall resource constraint:

$$
\mathrm{NL}=\mathrm{NX}+\mathrm{N}\left(\mathrm{L}_{\mathrm{Y}}+\mathrm{L}_{\mathrm{Z}}\right)+\mathrm{G}
$$

Individuals maximize the Lagrangian:

$$
\mathrm{U}\left(\mathrm{X}, \mathrm{Y}, \mathrm{L}_{\mathrm{H}}, \mathrm{G}, \mathrm{E}\right)+\lambda\left\{\left(1-\mathrm{t}_{\mathrm{L}}\right) \mathrm{L}+\left(1-\mathrm{t}_{\Pi}\right) \Pi-\mathrm{X}-\mathrm{p}_{\mathrm{Y}} \mathrm{Y}\right\}
$$

by their choice of $\mathrm{X}, \mathrm{Y}$, and $\mathrm{L}_{\mathrm{H}}$, where $\mathrm{t}_{\mathrm{L}}$ is the tax rate on resource (labor) supply, $\mathrm{t}_{\Pi}$ is the tax rate on profits, and $\Pi$ are profits. Economic profits can arise from two sources in this model. First, the cap and trade program provides scarcity rents for firms that receive permits (equal to the market value of the permits received). Second, profits will arise if $\mathrm{Y}$ is produced by a monopolist. In this section, we focus on profits arising from the cap and trade program. Later we introduce monopoly production and profits.

Our approach is to start at an initial competitive equilibrium with an existing tax on labor, but without any policy correction for the external effect of $\mathrm{Z}$ on $\mathrm{E}$, and then to analyze small changes. Following the log-linearization approach used by Bovenberg and de Mooij (1994), Fullerton and Metcalf (2001), and others, we differentiate all equations above and re-express them in terms of proportional changes $(\hat{\mathrm{L}} \equiv \mathrm{dL} / \mathrm{L})$. We then solve for the change in utility, dU, divide by $\lambda$ to express the change in dollars, and divide by $\mathrm{L}$ to get the dollar gain or loss as a fraction of income:

$$
\frac{\mathrm{d} U}{\lambda \mathrm{L}}=\mathrm{t}_{\mathrm{L}} \hat{\mathrm{L}}-\mu\left(\frac{\mathrm{Z}}{\mathrm{L}}\right) \hat{\mathrm{Z}}
$$

where $\mu=-\mathrm{NU}_{\mathrm{E}} \mathrm{e}^{\prime} / \lambda$ is the "marginal environmental damage" (MED). A new environmental regulation can be represented by a small exogenous reduction in pollution $(\hat{Z}<0)$. We then need to solve for the endogenous change in labor supply. Once we have $\hat{\mathrm{L}}$, equation (5) says that welfare is lowered to the extent that this policy reduces labor supply (because of the pre-existing tax on labor, $\mathrm{t}_{\mathrm{L}}$ ). Also, welfare is raised to the extent that the policy reduces pollution. 
Next, in order to derive an expression for the change in labor supply, $\hat{\mathrm{L}}$, we need to trace the effect of the policy $(\hat{Z}<0)$ on the price of emissions, the price of output, and thus on the real net wage. We also trace the effect of the policy on income flows that might affect labor supply. These income effects include the possibility that the policy generates private profits.

Any policy to reduce $\mathrm{Z}$ will raise the marginal product of $\mathrm{Z}$ above its private cost. In the case of the Clean Air Act, the limited number of permits are handed out for free (on the basis of historic energy use). Thus the scarcity rent goes to the permit recipient. These permits can be used to yield a marginal product greater than the private cost of emissions, or they can be sold. Either way, the policy has generated a private profit. We define these profits as:

$$
\Pi=\left(\mathrm{p}_{\mathrm{Z}}-1\right) \mathrm{Z}
$$

The rules for the initial allocation of these permits do not matter in our model, because our $\mathrm{N}$ identical agents must own whatever firm or other entity is given the permits. The price $\mathrm{p}_{Z}$ in equation (6) is the marginal value of emissions, and the private cost of emissions is 1 , so $\left(\mathrm{p}_{\mathrm{Z}}-1\right)$ is the market price of the tradable allowance. ${ }^{7}$ Note that while the profits are initially given to the firms, they can be recovered by the government through taxation $\left(\mathrm{t}_{\Pi}\right)$. As seen below, the tax rate on profits will be an important policy instrument.

We start at a competitive equilibrium with no environmental policy and zero profits. Thus, $\mathrm{p}_{Z}=1$, and $\Pi$ in equation (6) is zero. When we introduce a new policy to restrict emissions, any generated profits might affect consumer behavior and government revenue.

The government budget constraint is:

$$
\mathrm{G}=\mathrm{Nt}_{\mathrm{L}} \mathrm{L}+\mathrm{Nt}_{\Pi} \Pi
$$

The environmental policy affects labor supply and profits, so it also affects government revenue. In order to hold spending on $\mathrm{G}$ constant, we assume that government adjusts the labor tax to balance the budget. We differentiate the government budget ( 7 ) and set $\mathrm{dG}=0$ to calculate the necessary change in $t_{L}$. For notational convenience, it is expressed below as a proportion of the net wage $\left(\hat{\mathrm{t}}_{\mathrm{L}} \equiv \mathrm{dt}_{\mathrm{L}} /\left(1-\mathrm{t}_{\mathrm{L}}\right)\right)$.

\footnotetext{
${ }^{7}$ Current prices for $\mathrm{SO}_{2}$ allowances at the end of 1999 were roughly $\$ 150$ per ton of emissions. See U.S. Environmental Protection Agency (2000). If instead of creating restrictions through a cap and trade program, the government simply restricted emissions, then $\mathrm{p}_{\mathrm{Z}}$ would be a shadow price rather than a market price.
} 
We set $t_{\Pi}$ to 1 for any case where government receives the scarcity rent, such as for sale of permits, and we set it to zero for the other extreme where private parties keep the rents. This specification also allows us to consider the case where a pre-existing corporate profits tax rate would take part of the firm's private profits. We do not adjust this tax rate endogenously to help maintain the necessary revenue to pay for $\mathrm{G}$, but its existence greatly affects the amount by which the labor tax might have to be adjusted. Suppose, for example, that a permit or CAC policy generates profits but also reduces labor supply and thus labor tax revenue. If the tax on profits is zero, then the government has to raise the labor tax rate and exacerbate labor supply distortions. If $\mathrm{t}_{\Pi}$ equals 1 , then the government may be able to reduce the labor tax rate.

To obtain specific effects on labor supply, we assume that utility is separable in the form $\mathrm{U}=\mathrm{U}\left(\mathrm{V}\left\{\mathrm{Q}(\mathrm{X}, \mathrm{Y}), \mathrm{L}_{\mathrm{H}}\right\}, \mathrm{G}, \mathrm{E}\right)$, where $\mathrm{Q}$ is a homothetic function of $\mathrm{X}$ and $\mathrm{Y}$. If $\mathrm{p}_{\mathrm{Q}}$ is a price index on $\mathrm{Q}(\mathrm{X}, \mathrm{Y})$, then the real net wage is $\mathrm{w}=\left(1-\mathrm{t}_{\mathrm{L}}\right) / \mathrm{p}_{\mathrm{Q}}$. Differentiation yields $\hat{\mathrm{w}}=-\hat{\mathrm{t}}_{\mathrm{L}}-\hat{\mathrm{p}}_{\mathrm{Q}}$. Also, $\hat{\mathrm{p}}_{\mathrm{Q}}=\phi \hat{\mathrm{p}}_{\mathrm{Y}}$, where $\phi$ is the expenditure share of the dirty good in the consumer's budget, so:

$$
\hat{\mathrm{w}}=-\hat{\mathrm{t}}_{\mathrm{L}}-\phi \hat{\mathrm{p}}_{\mathrm{Y}}
$$

The consumer's maximization of (4) yields a labor supply function that can be written as $\mathrm{L}=\mathrm{L}\left(\mathrm{w},\left(1-\mathrm{t}_{\Pi}\right) \Pi / \mathrm{p}_{\mathrm{Q}}\right)$. If profits were always zero, then $\mathrm{L}$ depends only on the real net wage, $w$, and differentiation yields $\hat{\mathrm{L}}=\varepsilon \hat{\mathrm{w}}$, where $\varepsilon$ is the uncompensated labor supply elasticity. However, labor supply also depends on income effects from the change in real net profits. We differentiate all equations to show how the emission restriction raises the value of emissions $\mathrm{p}_{Z}$, which affects profits and raises the price of output. This raises $\mathrm{p}_{\mathrm{Q}}$, which lowers the real net wage w, which affects labor supply $\mathrm{L}$.

For the analysis that follows, we make a simplification of the model to avoid notational clutter and undue complexity. We assume that the output $\mathrm{Y}$ itself generates externalities either in production or in consumption. In other words, we assume $\mathrm{Y}=\mathrm{Z}$ (and $\mathrm{L}_{\mathrm{Y}}=0$ ). ${ }^{8}$ Thus $\hat{\mathrm{Y}}=\hat{\mathrm{Z}}$, and $\hat{\mathrm{p}}_{\mathrm{Y}}=\hat{\mathrm{p}}_{\mathrm{Z}} \cdot{ }^{9}$ As we discuss below, this simplification affects the quantitative but not the

\footnotetext{
${ }^{8}$ Examples include gasoline, and cigarettes, where the environmental problem is not from one of the inputs to production, but from the use of the final product. For these two examples, it is easy to see how a mandated reduction of every firm's output (pollution) could generate private profits.

${ }^{9}$ The marginal cost of production of $\mathrm{Y}$ is then simply the marginal cost of $\mathrm{Z}$, which we assume equal to 1 . In this case, the change in the price to consumers directly reflects the increased cost of pollution.
} 
qualitative results. With this simplification, we find that: ${ }^{10}$

$$
\hat{\mathrm{L}}=\left(1-\mathrm{t}_{\Pi}\right)\left[\frac{\left(1-\mathrm{t}_{\mathrm{L}}\right) \phi(\eta-\varepsilon)}{\left(1-\mathrm{t}_{\Pi}\right) \phi(\eta-\varepsilon)-\sigma_{\mathrm{Q}}(1-\phi)\left(1-\mathrm{t}_{\mathrm{L}}-\varepsilon \mathrm{t}_{\mathrm{L}}\right)}\right] \hat{\mathrm{Y}} \equiv\left(1-\mathrm{t}_{\Pi}\right) \Delta \hat{\mathrm{Y}}
$$

where $\eta$ is the income elasticity of labor supply, and $\sigma_{Q}$ is the elasticity of substitution between $\mathrm{X}$ and $\mathrm{Y}$ in consumption. This equation provides $\hat{\mathrm{L}}$ as a function only of exogenous parameters and the policy shock $(\hat{Y})$.

A couple of comments are in order. First, the ratio in brackets (denoted $\Delta$ ) will be positive if the following three assumptions hold: leisure is a normal good $(\eta<0)$; labor supply is not backward-bending $(\varepsilon \geq 0)$; and $\varepsilon<\left(1-\mathrm{t}_{\mathrm{L}}\right) / \mathrm{t}_{\mathrm{L}}$. We assume these three conditions hold throughout. ${ }^{11}$ Thus, with $\Delta>0$, labor supply in (9) moves in the same direction as production of the dirty good $(\hat{Y})$ when the cap and trade program is implemented.

Second, equation (9) shows the importance of $t_{\Pi}$. If government acquires all the rents for use in reducing labor tax rates (that is, if $t_{\Pi}=1$ ), then the policy will not affect labor supply and will not exacerbate labor tax distortions. Otherwise, labor supply will fall. Finally, we can combine equations to measure explicitly the welfare loss from the cap and trade policy. We substitute equation (9) into (5) to obtain the welfare impact:

$$
\frac{d U}{\lambda L}=\left[t_{L}\left(1-t_{\Pi}\right) \Delta-\mu\left(\frac{Y}{L}\right)\right] \hat{Y} \equiv-\psi \hat{Y}
$$

Utility increases only if the cost of the larger labor supply distortion $\left(t_{L}\left(1-t_{\Pi}\right) \Delta\right)$ is less than the benefits from reducing pollution $(\mu \mathrm{Y} / \mathrm{L})$. Since $\hat{\mathrm{Y}}$ is negative, the sign of $\psi$ indicates the net effect on welfare.

\section{Benchmark Results with Perfect Competition}

In this section we provide numerical magnitudes for the welfare loss from an incremental

\footnotetext{
${ }^{10}$ See Fullerton and Metcalf (1997) for details.

${ }^{11}$ The third condition will be satisfied if the initial point is on the normal side of the Laffer curve. Define revenue as $\mathrm{R}=\mathrm{t}_{\mathrm{L}} \mathrm{L}$, totally differentiate, and rearrange to get $\hat{\mathrm{R}} / \hat{t}_{\mathrm{L}}=\left(1-\mathrm{t}_{\mathrm{L}}\right) / \mathrm{t}_{\mathrm{L}}-\varepsilon$.
} 
cap and trade restriction for our model under perfect competition. In order to provide results, we need to select plausible parameter values for (10). These will also be useful for subsequent calculations in the monopoly case. For $t_{L}$, we want a tax rate that applies to income from all household resources (that is, national income). Total government spending in the U.S. is roughly $35 \%$ of national income, but incentives depend on a marginal tax rate that exceeds this average tax rate. We feel that $t_{\mathrm{L}}=0.5$ would be a reasonable choice to account for the progressive Federal income tax, plus payroll tax, plus state and local income taxes, plus sales and excise taxes. All of these taxes apply to market goods and not to leisure. However, we actually use $t_{L}$ $=0.4$, because the rate in our model is both an average rate and a marginal rate. ${ }^{12}$

For the uncompensated labor supply elasticity $\varepsilon$, we need a single value to represent an aggregate of all potential workers and all labor supply effects from changes in wages. As discussed in Rosen (1980), these effects include not only hours worked, but also participation decisions and effort on the job. Thus, the typical hours elasticity likely understates the overall impact of changes in the real net wage. The literature includes many estimates of the hours elasticity that are small or negative for men, and other estimates that are large and positive for women. $^{13}$ These estimates do not include participation decisions. Few have attempted to aggregate and summarize all such effects into one number. One such attempt is in Russek (1996). Taking into account both hours and participation, using many existing estimates for both men and women, he concludes that "the total wage elasticity for the labor supply of the economy seems to range somewhere between zero and $0.3 "$ (p.10). ${ }^{14}$ In this study, we employ both 0.1 and 0.3 as reasonable alternatives for the overall uncompensated wage elasticity $(\varepsilon)$.

Russek (1996) also finds that the aggregate income elasticity is about -0.30 for women and about -0.10 for men. We use -0.2 for the aggregate income elasticity $(\eta)$, so the compensated labor supply elasticity $(\varepsilon-\eta)$ is either 0.3 or 0.5 . Note, by the way, that CAC or permit polices will still affect non-environmental welfare even if $\varepsilon$ were 0 , because the creation of profits generates an income effect that reduce labor supply and thus still exacerbate pre-

\footnotetext{
${ }^{12}$ An overall labor tax rate of 0.4 has become a standard assumption in the literature on marginal excess burden, including Stuart (1984) and Browning (1987).

${ }^{13}$ In a questionnaire sent to labor economists, Fuchs et al. (1998) find that the mean belief is that the hours elasticity is zero for men and 0.45 for women.

${ }^{14}$ Feldstein (1995) points out other behavioral alternatives to taxable labor supply, and he finds that the relevant elasticity is at least 1.0 and could be higher.
} 
existing distortions.

Estimates for the elasticity of substitution in consumption, $\sigma_{\mathrm{Q}}$, are not available for the specific aggregation in our model between a "clean" good X and a "dirty" good Y. We choose a base value of 1.0 , which is broadly consistent with the empirical literature on substitution in consumption, and we test the sensitivity of results to alternative values.

For $\phi$, we want an aggregate expenditure share for all goods with externalities in production or consumption. Based on 1993 data in the Statistical Abstract of the United States (U.S. Bureau of the Census 1999)), the industries most responsible for pollution include chemical and paper producers, mining and primary metals, electric utilities, petroleum and coal production and processing, and motor vehicles and equipment. Total production by those industries constitutes almost $15 \%$ of GDP, so we use 0.15 for $\mathrm{Y} / \mathrm{L}$. Since $\phi$ is defined as $\mathrm{p}_{\mathrm{Y}} \mathrm{Y} /\left\{\mathrm{L}\left(1-\mathrm{t}_{\mathrm{L}}\right)\right\}$, and since $t_{L}=0.4$, we must have $\phi=1 / 4$. In other words, these polluting goods are primarily private goods, so $15 \%$ of total output represents a quarter of private consumption. ${ }^{15}$

Finally, we need a measure of marginal environmental damage $(\mu)$. Pearce and Turner (1990) review studies finding that damages from pollution are $0.5 \%$ to $0.9 \%$ of GNP in the Netherlands. Wicke (1990) reports estimates that are 6\% of GNP in Germany. Freeman (1982, 2002) estimates that pollution damages would be about $1.25 \%$ of GNP or higher in the U.S. in the absence of environmental polices. ${ }^{16}$ Unfortunately, none of these sources provides a measure of marginal damages. Based on the figures just mentioned, we assume that total damages are 1.5\% of total output. Then, since $\mathrm{Y}$ is $15 \%$ of total output, we have damages that are about $10 \%$ of Y. Again we use multiple alternatives. First, if this relationship were linear, then damages would be about $10 \%$ of marginal output $(\mu=0.1)$. Second, however, these surveys do not include damages from greenhouse gas emissions. Focusing on carbon emissions by the electric power industry, Nordhaus (1991) reports estimates of MED ranging from a low of \$7 per ton to a high of $\$ 66$ per ton. Parry et al. (1999) argue that typical estimates are below $\$ 20$ per ton (p. 67). We need to convert this number to damages per dollar of output. Carbon emissions associated with electric power totaled 607.2 million metric tons in 1998 according to Energy Information Administration (2001), and Gross Domestic Product for electric utility services is roughly \$122.7

\footnotetext{
${ }^{15}$ In any case, as shown in Goulder et al. (1997), results are not sensitive to this parameter.

${ }^{16}$ Recent estimates by the EPA are much higher (on the order of one-fifth of GDP for 1990) as reported in U.S. Environmental Protection Agency (1997). Freeman (2002) notes that these estimates are controversial.
} 
billion in that year. ${ }^{17}$ By division, we get 0.0050 tons of carbon per dollar of GDP in this industry. Thus, $\$ 20 /$ ton is 10 percent of the value of output $(\mu=0.1)$.

Given the tremendous uncertainty associated with this number, we also provide results for a case with "treble damages" $(\mu=0.3)$. Finally, as an alternative to reporting any specific value of $\mu$, we also report the threshold value of $\mu$ above which the welfare impact of the pollution reduction becomes positive.

Table 1 shows the effects of a permit or CAC policy that mandates a small reduction in the quantity of the polluting good $(\hat{Y}<0)$. The left-hand section shows assumed values for some of the input parameters. The first four rows show results for $t_{L}=0.4$, while we vary $\varepsilon$ and $\mu$. When marginal damage $\mu$ is 0.1 , then column 1 shows that a $1 \%$ reduction in Y yields benefits from reduced pollution that are $0.015 \%$ of national income. In the first row where $\varepsilon$ is also 0.1 , and scarcity rents are not taxed $\left(\mathrm{t}_{\Pi}=0\right)$, we find that $\Delta=0.09$ (so a $1 \%$ reduction in output of $\mathrm{Y}$ induces a $0.09 \%$ reduction in labor supply). Multiplication by the tax rate ( 0.4$)$ yields a welfare cost from the labor supply reduction that is $0.036 \%$ of national income. Taking into account both the environmental gain (0.015) and the labor market loss (-0.036), we find that the net effect is a reduction in welfare equal to $0.021 \%$ of national income. As noted in column (4), the output restriction will reduce welfare so long as $\mu$ is less than 0.240 . Using a similar model with perfect competition, Parry (1997) also finds that pollution quotas can reduce welfare in the presence of pre-existing labor tax distortions.

With a 40 percent tax on rents $\left(t_{\Pi}=t_{L}\right)$, where those revenues are used to reduce the labor tax rate, the added labor market distortion is only 0.023 (rather than 0.036). This figure still exceeds the 0.015 environmental gain, by 0.008 of national income. If we continued to increase the tax on rents, the loss from the labor distortion would continue to fall. Note that the threshold value of marginal damages has fallen from 0.240 to 0.153 . Recapturing some of the rents raises the likelihood that the policy will be welfare improving in the case with uncertainty about $\mu$.

The breakeven tax rate, the rate at which the environmental benefits of the permit policy are just offset by the increased labor market distortions, is 62 percent (see column $(8)) .{ }^{18}$ In the

\footnotetext{
${ }^{17}$ GDP is reported for electric, gas, and sanitary services. Electric utility services are 59.9 percent of gross output for this cluster of industries. We apply that fraction to the whole industry's GDP to obtain our estimate.

${ }^{18}$ Giving away permits corresponds to $t_{\Pi}=0$, while selling them corresponds to $t_{\Pi}=1$. A hybrid policy where some are sold and others given away is possible, and so $t_{\Pi}$ between 0 and 1 is possible. Bovenberg and Goulder (2001) consider such a hybrid policy.
} 
limit, with 100 percent capture of scarcity rents $\left(t_{\Pi}=1\right)$, then labor supply is unaffected (equation (9)). An environmental policy that collects all of the scarcity rents can eliminate the negative effects on the pre-existing labor distortion. This policy can have unambiguously positive effects on welfare. ${ }^{19}$ Notice, however, that 100 percent capture is necessary just to get all of the benefits from the environment.

The second row of Table 1 changes the wage elasticity from 0.1 to 0.3 , so the negative effect on labor is enlarged. Welfare falls even more. The point is that when environmental controls raise production costs, the lower real net wage can reduce effort on the job, induce secondary workers to quit, or even shift the same effort from taxable to nontaxable forms like home production or the underground economy. As taxable labor supply becomes more responsive, the environmental policy is less likely to raise welfare. In this scenario, the breakeven tax rate on profits is over 80 percent.

The next two rows triple the marginal environmental damage (from 0.1 to 0.3 ). If the labor supply elasticity is back down to 0.1 , then the environmental gain $(0.045)$ exceeds the loss from the labor distortion (0.036). Even with "treble damages," this policy just barely raises welfare (by 0.009) with a zero profits tax. Still, however, the taxation of scarcity rents can reduce the labor market loss and leave more of the environmental gain.

When both parameters are 0.3 , the large environmental gain $(0.045)$ is more than offset by the larger loss from labor distortions (0.062) when scarcity rents are untaxed. As indicated in column (4), the MED would have to be over $40 \%$ of the firm's production cost for this environmental regulation to break even in terms of welfare. In particular examples, the externality might well be high, perhaps over $100 \%$ of the firm's production cost. The point remains, however, that even a large gain from correcting a large externality can be offset by losses from labor market distortions - unless the government captures the scarcity rents. In the fourth row (where both parameters are 0.3$)$, the $40 \%$ tax on rents converts the net loss $(-0.017)$ into a small net gain (0.004).

The last two rows of Table 1 illustrate the effect of altering the initial labor tax rate (keeping $\varepsilon$ and $\mu$ at 0.3 ). Consider column 3 (where $t_{\Pi}=0$ ). If $t_{L}$ is 0.3 , instead of 0.4 , the net

\footnotetext{
${ }^{19}$ This case with $t_{\Pi}=1$ corresponds exactly to the case of Bovenberg and de Mooij (1994) where a tax on the dirty good generates revenues used to reduce the tax on labor income. See equation (13) in their paper, when their initial $\mathrm{t}_{\mathrm{D}}=0$.
} 
welfare effect is a small net gain (0.007) instead of a loss $(-0.017) .^{20}$ Note, however, that this 0.007 net gain is still only a small fraction of the 0.053 gain possible with government capture of the rents. If the initial tax rate is raised to 0.50 , then the welfare loss is increased from -0.017 to -0.043 . If scarcity rents are not taxed and the tax on labor income is $50 \%$, then the marginal environmental damage $(\mu)$ would have to be over $60 \%$ of production cost before the regulatory policy could begin to improve welfare.

In calculations not reported here, we have also considered a model in which pollution and labor are inputs in the production of a dirty good and firms can substitute between these two inputs (reduce pollution by the use of more resources). Not surprisingly, the welfare impact of a cap and trade program depends importantly on the elasticity of substitution between the dirty and clean input. For an elasticity below one, we find that the welfare losses of the pollution restriction increase. For example, in the scenario corresponding to the fourth row of Table 1, the net welfare loss rises from -0.017 to -.077 as the elasticity falls from one to zero. Increasing the elasticity from one to two shifts the welfare loss to a small welfare gain (0.004). See Fullerton and Metcalf (1997) for more details on these calculations.

A permit policy like the Clean Air Act Amendments of 1990 creates a scarcity rent that is left in private hands. It does not necessarily improve welfare, in this second-best world, even when starting with a substantial uncorrected externality.

\section{Model and Results with Monopoly Production}

To this point, we have assumed that all markets are perfectly competitive, but we now explore how environmental policies affect welfare in the presence of imperfect competition. To be specific, we consider the case where the polluting good $(\mathrm{Y})$ is provided by a monopolist. ${ }^{21} \mathrm{We}$ motivated this research by noting the possibility of market power in the electric utility industry, an industry subjected to cap and trade restrictions in 1990. The phenomenon of monopoly power in polluting industries is more general. Hall (1986) reports mark-up ratios by industry using post-

\footnotetext{
${ }^{20}$ When $t_{L}$ changes from 0.4 to 0.3 , we assume that $\phi$ remains at $1 / 4$, so $\mathrm{Y} / \mathrm{L}=\phi\left(1-\mathrm{t}_{\mathrm{L}}\right)$ must change (from 0.15 to $0.18)$.

${ }^{21}$ If instead the clean sector has monopoly power, then the regulatory reduction in $\mathrm{Y}$ will offset the monopolist's reduction in $\mathrm{X}$, but it will reinforce the wage tax effect by reducing both goods relative to leisure. Also, the model could incorporate other forms of imperfect competition. Browning (1997) uses a simple mark-up to represent an arbitrary degree of market power, but we wish to specify monopoly behavior in order to see how that mark-up changes. We believe that our results would not be substantially different with some other specific model of oligopoly
} 
World War II data and separates industries into groups exhibiting "substantial," "some," and "little" market power (his Table 1, p. 298). Of the seven industries included in his category exhibiting substantial market power, four are significant polluting industries (chemicals, paper, motor vehicles, and primary metals). Three of the polluting industries (metal mining, utilities, and oil and gas extraction) have high but unreliably estimated mark-up ratios. Only one polluting industry (other transportation equipment) is included in the group exhibiting little mark-up. ${ }^{22}$

Aside from allowing for a polluting monopolist, we maintain the model developed in the previous sections. Our economy now has three pre-existing distortions: a wage tax, a monopolist, and an uncorrected externality. As a consequence, the welfare effect of any particular change cannot be known a priori. The initial production of $\mathrm{Y}$ may be too low because of monopoly, or too high because of the externality. Similarly, even the initial labor supply may be above or below the welfare-maximizing level. Any environmental policy that requires a reduction in $\mathrm{Y}$ will alleviate some problems and exacerbate others. We solve for the general equilibrium effect of a small policy on all three distortions.

The production relationships are linear as in our first model above. The household budget constraint in (4) is unaffected, but after-tax monopoly profits $\left(1-t_{\Pi}\right) \Pi$ exist prior to the implementation of any environmental policy. These profits are defined by:

$$
\Pi=\left(p_{Y}-1\right) Y
$$

If $\mathrm{Y}$ is produced in a competitive market, then the initial equilibrium price of $\mathrm{Y}\left(\mathrm{p}_{\mathrm{Y}}\right)$ equals 1 . If $\mathrm{Y}$ is produced by a monopolist, then the firm maximizes profits by choosing $\mathrm{Y}$ (or equivalently $p_{Y}$, given the demand curve). We define $\varepsilon_{Y}$ as the absolute value of the price elasticity of demand for $\mathrm{Y}$, so the firm's first-order condition for profit maximization is: ${ }^{23}$

$$
\mathrm{p}_{\mathrm{Y}}-1=\frac{\mathrm{p}_{\mathrm{Y}}}{\varepsilon_{\mathrm{Y}}}
$$

The degree to which the price of Y exceeds marginal cost depends on the elasticity of demand

\footnotetext{
or monopolistic competition, but we leave these questions for future research.

${ }^{22}$ Evidence supporting market power in polluting industries can also be found in Domowitz et al. (1988), Beccarello (1996), and Considine (2001).

${ }^{23}$ Totally differentiate (11), set $\mathrm{d} \Pi$ to zero, and re-arrange.
} 
for Y. The higher is $\varepsilon_{\mathrm{Y}}$, the less distortion (mark-up) is created by monopolization of $\mathrm{Y}$. Equation (12) can only be satisfied if the monopolist produces in the portion of the demand curve where the elasticity is greater than one. ${ }^{24}$

Totally differentiating the definition of profits in (11), and using the first order condition for the monopolist in (12) yields:

$$
\hat{\Pi}=\hat{\mathrm{Y}}+\varepsilon_{\mathrm{Y}} \hat{\mathrm{p}}_{\mathrm{Y}}
$$

Also, along a demand curve where income and other prices are constant, the consumer's behavior is defined by:

$$
\hat{\mathrm{Y}}=-\varepsilon_{\mathrm{Y}} \hat{\mathrm{p}}_{\mathrm{Y}}
$$

The firm uses the demand curve in (14) to arrive at its maximizing behavior, so substitution into (13) yields $\hat{\Pi}=0$. That is, the firm cannot increase profits by movement in either direction along the demand curve. We use (13) to calculate a change in profits that is not zero, however, for an environmental regulation that shifts the demand curve by changing income and other prices. Also, occasionally, it will be useful to write profits as:

$$
\Pi=\left(p_{\mathrm{Y}}-1\right) \mathrm{Y}=\frac{\mathrm{p}_{\mathrm{Y}} \mathrm{Y}}{\varepsilon_{\mathrm{Y}}}
$$

where the first equality reflects the definition of profits in (11) and the second equality reflects the firm's behavior in (12). The far-right expression for profits is written in terms of $\varepsilon_{Y}$, the demand elasticity for $\mathrm{Y}$. Next, we express $\varepsilon_{\mathrm{Y}}$ in terms of $\sigma_{\mathrm{Q}}$.

Differentiating the household budget constraint (holding income constant) yields:

$$
\hat{X}=-\frac{\phi}{1-\phi}\left(\hat{Y}+\hat{p}_{Y}\right) .
$$

\footnotetext{
${ }^{24}$ We set parameters below such that the initial $\mathrm{p}_{\mathrm{Y}}$ is 1.2 , so profits are $20 \%$ of the cost of producing $\mathrm{Y}$. This is consistent with the estimates of market power reported in Office of Policy (2000). Equation(12) then implies that $\varepsilon_{Y}$ is six. We also derive the corresponding value of $\sigma_{\mathrm{Q}}$, which also must exceed one.
} 
Then, combining equations (14), (16), and the definition of the elasticity of substitution in consumption, we have:

$$
\varepsilon_{\mathrm{Y}}=\phi+(1-\phi) \sigma_{\mathrm{Q}}
$$

Since $\varepsilon_{Y}$ must exceed 1 , the monopoly solution also requires that $\sigma_{\mathrm{Q}}$ exceed 1 .

To obtain an expression for the welfare impact of regulation in the presence of monopoly, we follow steps similar to those in the derivation of $d U / \lambda \mathrm{L}$ above. We totally differentiate utility and use first-order conditions from the consumer's maximization problem, but we also use the definition of profits. These steps yield:

$$
\frac{d U}{\lambda L}=t_{L} \hat{L}-\mu\left(\frac{Y}{L}\right) \hat{Y}+\left(\frac{\Pi}{L}\right) \hat{Y}
$$

As before, the environmental policy lowers welfare to the extent that it reduces labor supply, and raises welfare to the extent that it reduces production of the polluting good. The third term represents the monopoly distortion. Since a monopolist inefficiently restricts production of its good, further restrictions from the environmental policy reduce welfare. The usual partial equilibrium model might compare the last two terms to see if the monopolist raises price toward (or above) the social marginal cost of output. For example, if the initial $\mathrm{p}_{\mathrm{Y}}$ is 1.2 , then profits are $20 \%$ of the cost of production of $\mathrm{Y}$. But if $\mu=0.2$, then these two effects exactly offset: the monopolist already raises price to 1.2 , which exactly reflects the social marginal cost of production $(1+\mu)$. However, that partial equilibrium model neglects the effect of $\hat{\mathrm{Y}}$ on $\hat{\mathrm{L}}$ in the first term of (18). We show below that labor supply, and thus welfare, must fall. The implication is that the reverse policy with a forced increase in output would raise welfare (despite the negative externality). ${ }^{25}$

These results depend entirely on whether the monopolist has left the price of output below the social marginal cost of production or has already raised it above the social marginal cost of

\footnotetext{
${ }^{25}$ An important issue is how to specify the counterfactual. Under one scenario, we could take Y/L from the previous competitive model, and suppose that $\mathrm{Y}$ were to become monopolized. We would then calculate a new lower $\mathrm{Y} / \mathrm{L}$ for the monopoly case, and a new lower benefit from reduction of pollution $(\mu \mathrm{Y} / \mathrm{L})$. Under a different scenario, $\mathrm{Y} / \mathrm{L}$ is an observed value like 0.15 , and we ask what would happen if that outcome represents a monopolized sector instead of a competitive sector. We take this latter course, since it maintains the size of the polluting sector (and thus $\mu \mathrm{Y} / \mathrm{L})$ across the two models.
} 
production. Therefore, in numerical results below, we use $\mathrm{p}_{\mathrm{Y}}=1.2$, and set $\mu$ to 0.1 or 0.3 .

To find the general equilibrium effect on labor supply, we again start with the government's balanced-budget adjustment to the tax rate on labor. Any pre-existing tax rate on profits is not adjusted. The government budget constraint in equation (7) is unchanged, but now profits exist prior to the imposition of any new policy. Moreover, the change in profits is driven by equation (16). We differentiate equation (7), use the expression for profits in equation (15) as well as the change in profits in equation (13) to obtain:

$$
\hat{\mathrm{t}}_{\mathrm{L}}=-\left(\frac{\mathrm{t}_{\mathrm{L}}}{1-\mathrm{t}_{\mathrm{L}}}\right) \hat{\mathrm{L}}-\left(\frac{\phi \mathrm{t}_{\Pi}}{\varepsilon_{\mathrm{Y}} \mathrm{S}_{\mathrm{L}}}\right)\left(\hat{\mathrm{Y}}+\varepsilon_{\varepsilon_{\mathrm{Y}}} \hat{\mathrm{p}}_{\mathrm{Y}}\right) .
$$

where $\mathrm{S}_{\mathrm{L}}$ is the share of after-tax labor income in total after-tax household income.

Next, labor supply is a function of the real net wage and real nonlabor income. Thus environmental regulations affect labor supply both through the effect of $\hat{t}_{L}$ on $\hat{w}$ and the effect of $\hat{Y}$ on $\hat{\Pi}$. We differentiate the labor supply function and use equation (13) to get:

$$
\hat{\mathrm{L}}=\varepsilon \hat{\mathrm{W}}+\eta \mathrm{S}_{\Pi}\left|\hat{\mathrm{Y}}+(1-\phi) \sigma_{\mathrm{Q}} \hat{\mathrm{p}}_{\mathrm{Y}}\right|
$$

where $S_{\Pi}$ is the share of after-tax profits in after-tax income. The expression in brackets is the proportional change in real profits. Labor supply is affected by changes in the real after-tax wage through $\varepsilon$ (including both substitution and income effects) as well as changes in real profits through $\eta$ (effect of nonlabor income).

Finally, we need an expression for the change in the price of $\mathrm{Y}$ attributable to the environmental policy. We can use the equilibrium relationship between $\mathrm{Y}$ and $\mathrm{p}_{\mathrm{Y}}$ to obtain this expression. Totally differentiate the household budget constraint:

$$
\hat{\mathrm{X}}=-\frac{\mathrm{p}_{\mathrm{Y}} \mathrm{Y}}{\mathrm{X}}\left(\hat{\mathrm{Y}}+\hat{\mathrm{p}}_{\mathrm{Y}}\right)+\frac{\left(1-\mathrm{t}_{\mathrm{L}}\right) \mathrm{L}}{\mathrm{X}}\left(\hat{\mathrm{L}}-\hat{\mathrm{t}}_{\mathrm{L}}\right)+\left(1-\mathrm{t}_{\Pi}\right) \frac{\Pi}{\mathrm{X}} \hat{\Pi}
$$

Substitute this equation into the definition of the elasticity of substitution in consumption $\left(\sigma_{\mathrm{Q}}\right)$, and use equations (13), (17), and (19) to get: 


$$
\hat{\mathrm{p}}_{\mathrm{Y}}=-\frac{\hat{\mathrm{Y}}}{\varepsilon_{\mathrm{Y}}}+\frac{\mathrm{S}_{\mathrm{L}}}{\left(1-\mathrm{t}_{\mathrm{L}}\right)\left(\varepsilon_{\mathrm{Y}} \mathrm{S}_{\mathrm{L}}-\phi_{\mathrm{t}_{\Pi}}\right)} \hat{\mathrm{L}}
$$

At this point, if we take $\hat{Y}$ as an exogenous policy parameter, we have four equations that are linear in four unknowns. By successive substitution, or Cramer's Rule, the four equations (8), (19), (20), and (22) can be solved for $\hat{\mathrm{p}}_{\mathrm{Y}}, \hat{\mathrm{t}}_{\mathrm{L}}, \hat{\mathrm{w}}$, and $\hat{\mathrm{L}}$. The long expression for $\hat{\mathrm{L}}$ is not worth repeating here, but we use it to measure the welfare impact of a required reduction in Y. Thus welfare in (18) can be re-expressed as $-\psi \hat{\mathrm{Y}}$.

For parameter values, we cannot use all the same selections as before. In the competitive model, where $p_{Y}=1$, we set $(Y / L)=0.15$ and $t_{L}=0.40$, so government provision must be $40 \%$ of output and X must be the remaining $45 \%$ of output. These ratios generate $\phi=0.250$ for the expenditure on $\mathrm{Y}$ as a share of the consumer's budget. In the monopoly model, we first assume that the monopolist has set $p_{Y}=1.2$, so that profits are $20 \%$ of the output of $\mathrm{Y}$. Second, we choose to match the share of $\mathrm{Y}$ in total output $(\mathrm{Y} / \mathrm{L})$ across models, to keep the pollution impacts comparable. But then the higher price on $\mathrm{Y}$ in the monopoly model means that consumers must be spending more of their income on $\mathrm{Y}$. We derive $\phi$ as the spending $\mathrm{p}_{\mathrm{Y}} \mathrm{Y}=(1.2)(.15)$ as a fraction of total consumer spending $\{(1.2)(.15)+.45\}$, so $\phi$ must be 0.286 in the monopoly model. Third, we can no longer assume a unit elasticity of substitution between $\mathrm{X}$ and $\mathrm{Y}$. Since $\mathrm{p}_{\mathrm{Y}}=1.2$, equation (12) says that $\varepsilon_{\mathrm{Y}}$ must be 6 , and equation (17) says that $\sigma_{\mathrm{Q}}$ must be 8 . These values may seem high, but our model only has two commodities. The reality that constrains the price charged by a monopolist from being even higher is that some other good can serve as a reasonably close substitute. Then, to be able to compare results, we use this value $\left(\sigma_{\mathrm{Q}}=8\right)$ in both the competitive model and in the monopoly model. ${ }^{26}$

Finally, in cases where the pre-existing $t_{\Pi}$ is positive, then the initial monopoly profits must be generating some tax revenue. In those cases, we keep government spending at $40 \%$ of national output by reducing the initial tax on labor supply according to: ${ }^{27}$

$$
\mathrm{t}_{\mathrm{L}}=\frac{\mathrm{G}}{\mathrm{NL}}-\mathrm{t}_{\Pi} \frac{\Pi}{\mathrm{L}}
$$

\footnotetext{
${ }^{26}$ When $\sigma_{\mathrm{Q}}$ is fixed across the two models, but $\phi$ is not, equation (17) says that $\varepsilon_{\mathrm{Y}}$ must be 6.25 in the competitive model and 6 in the monopoly model.
} 
Table 2 presents results for these parameters when $\mathrm{Y}$ is provided by a monopolist and for purposes of comparison, also in a perfectly competitive market. All rows assume that the labor supply elasticity $\varepsilon$ is 0.3 , and the first two rows vary the externality ( $\mu=0.1$ and 0.3 ). We first analyze results for the perfectly competitive model. Note that the results for this competitive model differ from those in Table 1, primarily by assuming a greater degree of substitutability between $\mathrm{X}$ and $\mathrm{Y}$ in consumption. And because consumers have this greater ability to substitute in consumption, the forced reduction in $\mathrm{Y}$ has less impact on raising the price of $\mathrm{Y}$. The consequence is a smaller decrease in the real net wage and a smaller loss from increasing the labor market distortion. To see the impact of increasing $\sigma_{\mathrm{Q}}$ from 1 to 8 , compare the first row of Table 2 to the second row of Table 1 (with the same $\varepsilon=0.3$ and $\mu=0.1$ ). The labor market loss is cut by more than $80 \%$, from 0.062 to 0.010 . Since this loss is so much smaller, and the environmental gain is still 0.015 , this change in $\sigma_{Q}$ has converted the overall effect on welfare from negative in Table 1 to positive in Table 2. The next row in Table 2 shows that increasing the MED from 0.1 to 0.3 also increases this net gain.

The remaining rows of Table 2 keep $\mu=0.3$ and show the effect of alternative values for the initial tax on profits. As in Table 1, a higher tax on profits reduces the handout of scarcity rent, which blunts the fall in labor supply attributable to that income effect. With $100 \%$ profits tax, in the last row, all incremental labor market distortions are eliminated. Then the net welfare effect is simply the gain from correcting the externality.

The right half of Table 2 presents results from the monopoly model. First, note that the initial tax rate on wage income is no longer fixed at $40 \%$. With pre-existing profits, a higher initial profits tax implies that a lower initial labor tax is required to raise $40 \%$ of national income. The first two rows present results for the case where profits are untaxed (and the labor tax is $40 \%$ ). The reduction in labor supply in the monopoly model is $70 \%$ of the reduction in the perfect competition model (as evidenced by the loss from the labor market distortion in columns 3 and 8 ). Households do not reduce labor supply as much in the monopoly model because the environmental policy reduces monopoly profits, and leisure is a normal good. When $\mu$ is only 0.1 , however, the net welfare effect of the regulation turns from positive in the competitive model to negative in the monopoly model. The reason is that this monopolist has already raised price

\footnotetext{
${ }^{27}$ We use the same tax rate for monopoly profits and scarcity rents, but it would simple to allow these rates to differ.
} 
$\left(\mathrm{p}_{\mathrm{Y}}=1.2\right)$ above social marginal cost $(1+\mu)$. The loss from exacerbating the monopoly distortion combined with the loss from exacerbating the labor distortion then exceeds the environmental gain. The aggravating impact of monopoly power is also reflected in the higher breakeven value for marginal environmental damages $\left(\mu^{*}\right)$ under monopoly.

When $\mu=0.3$, the monopolist with $p_{Y}=1.2$ has not restricted output "enough." In this case the loss from the monopoly distortion (0.03) is less than the environmental gain (0.045). Now the net welfare effect depends on the labor distortion. In the monopoly model, however, the loss from the labor distortion is only 0.007. Why? First, the impact on labor is reduced substantially by the use of $\sigma_{\mathrm{Q}}=8$, as mentioned above, in both the competitive model and the monopoly model. When consumers can substitute into other goods, the policy has smaller effect on the price of $\mathrm{Y}$. It therefore has smaller effect on the real net wage and on labor supply. Second, in the monopoly model, the environmental policy reduces pre-existing profits. The loss of income has a positive effect on labor, since leisure is normal, which provides a "partial offset" to the negative effect from the lower real net wage. These factors shrink $\hat{\mathrm{L}}$ to only -0.016 , which is multiplied by $t_{L}=0.4$ to get the loss in welfare ( 0.007$)$.

The last three rows of Table 2 show that changes in $t_{\Pi}$ have virtually no effect on the 0.007 loss from the labor distortion (column 7). ${ }^{28}$ Why? First, a higher initial profits tax means that the income effect (from the change in monopoly profits) is smaller. Thus the "partial offset" just mentioned is smaller, and labor supply does fall a bit more. The real wage falls by about 0.058 in all three rows, and profits fall by about -0.038 in all three rows, but the higher tax on profits makes the income effect smaller. With $100 \%$ profits tax, and no income effect to offset the wage effect, labor supply falls by the full $\varepsilon \hat{\mathrm{w}}$, which is $(0.3)(-0.058)=-0.017$. Second, even though the higher profits tax enlarges the effect on labor supply (slightly), it reduces the initial required labor tax. The net effect on welfare is the product, $t_{L} \hat{L}$, so these two effects offset each other, and the loss from the labor distortion is essentially unchanged.

The results from this section illustrate two points about environmental policies that restrict output. First, the exacerbation of distortions arising from imperfect competition can be very

\footnotetext{
${ }^{28}$ When the profits tax rate is zero, the $40 \%$ labor tax raises enough to provide spending that is $40 \%$ of total output (L). The penultimate row finds the single tax rate on both profits and labor $(38.8 \%)$ that raises the same revenue for the initial equilibrium. The last row considers a 100\% profits tax, so the same spending is possible with a labor tax of only $37 \%$. (We assume the firm continues to maximize profits despite a $100 \%$ tax rate).
} 
important and could potentially more than offset any gains from improving the environment, even ignoring effects on labor supply. This point may be particularly important for energy-producing industries. Second, these monopoly results affect the previous result in the competitive model where we emphasized that government could prevent the fall in the real net wage if it were to capture all of the scarcity rents by $100 \%$ profits tax, or by sale of all permits. This result does not hold in a model with pre-existing profits, because the environmental policy reduces those preexisting profits. In the case of complete profits taxation, for a $1 \%$ output restriction, profits fall by $-.038 \%$. This change requires government to increase the tax on wages to make up lost tax on profits. The result is that a $1 \%$ output restriction does reduce the real net wage (by $0.058 \%$ ).

\section{Conclusion}

This paper develops and applies a simple analytic general equilibrium model to evaluate the welfare impact of implementing a cap and trade program such as the tradable allowance program in the Clean Air Act Amendments of 1990. Numerical results can be obtained with a relatively small number of parameters. The model is sufficiently flexible to allow for competitive markets in the production of the good associated with pollution as well as a market dominated by a monopolist.

In both the competitive model and the monopoly model, the government's capture of rents created by giving allowances to private firms is important if the policy is to have a positive welfare impact. In all the calculations considered, whether the creation of an allowance program that restricts pollution raises welfare or not depends importantly on the extent of tax on rents (or capture of rents) generated by the allowance give-away.

The capture of rents from the permit program is somewhat less important in the monopoly model, however, because the environmental policy reduces monopoly profits in a way that offsets the generation of scarcity rents from the emission restriction. These two income effects on labor supply offset each other: while the new scarcity-rent income tends to reduce labor supply, the diminished monopoly income tends to increase labor supply. In addition, a price effect reduces the real net wage and thus tends to decrease labor supply.

Thus we find offsetting effects on prior labor tax distortions, and only numerical analysis can allow us to compare the relevant magnitudes. While the net income effect on labor supply is reduced, in the monopoly model, we find that the price effect is enlarged. The introduction of a 
cap and trade program in a market characterized by imperfect competition is more likely to reduce welfare, even after taking the environmental benefits into account. The intuition is straightforward: market power raises price and curtails production of a commodity (relative to production in a competitive equilibrium). A cap and trade program further raises price and curtails production; the labor market distortions arising from a decrease in the real net wage are exacerbated, and the environmental benefits of reducing pollution are offset by greater distortions elsewhere. 


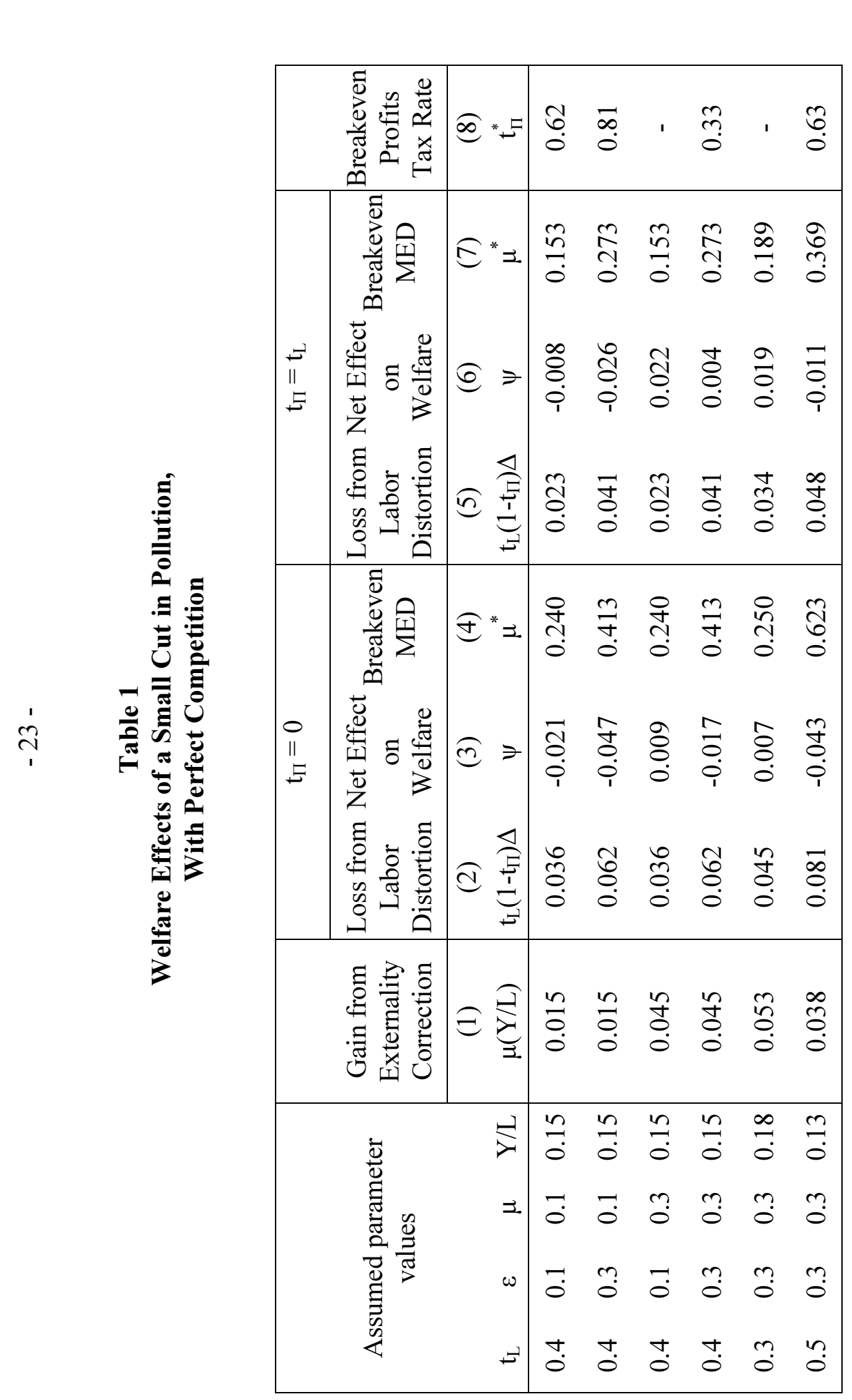

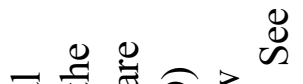

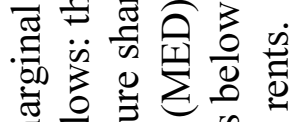

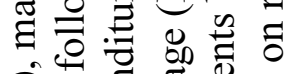
(4)

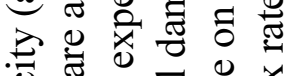
.0

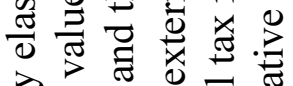
츈

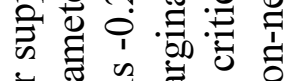

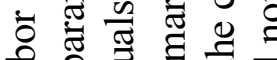

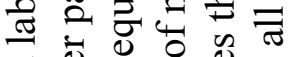

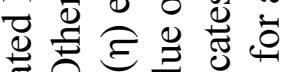
त्र

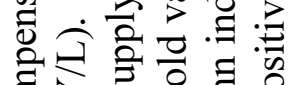
छぇ क

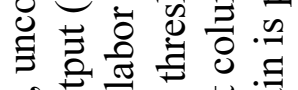
ङิ 元.

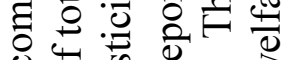

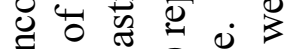

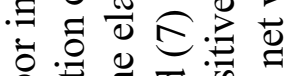

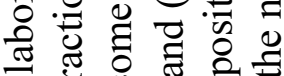
ฮี

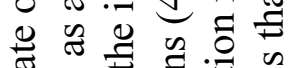
퓬 ชั

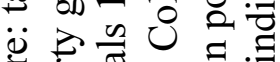

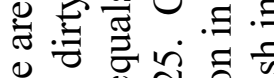

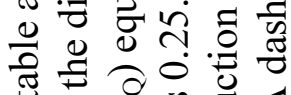
ษ

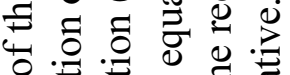

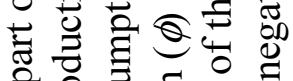

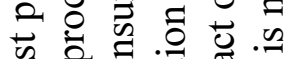

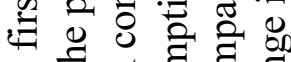
Ð $\Xi \Xi \Xi \Xi$ ‡ ๘

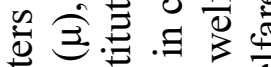
¿ 壳芯芯

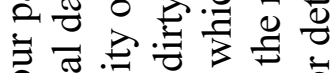

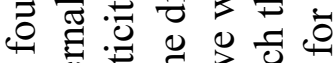

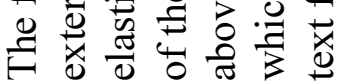




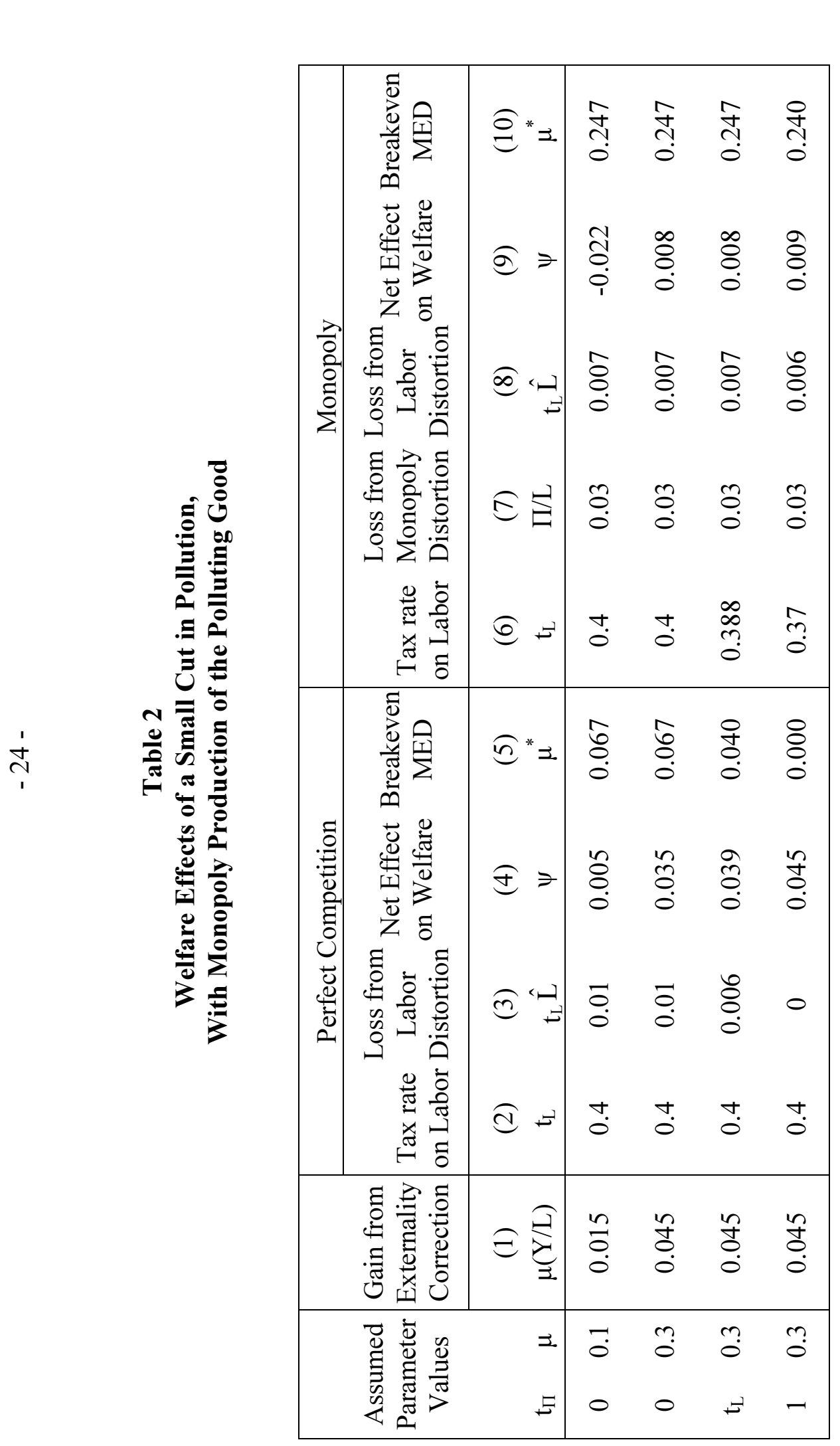

ஸ் ত্ৰ

1 专

= छ छ

륭

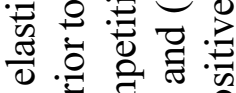

Е

ठैं

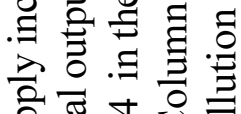

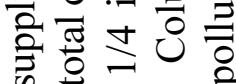

ப்

तิ 00 ○

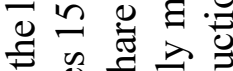

원 흉 흥

ก.

.

$\omega$ ठ $\dot{0} \Xi$

穿客

की

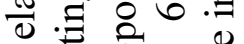

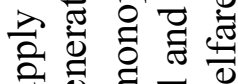

急

ธิธี 을

园寻 0

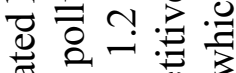

ष $\overline{0}$

Е ज छ

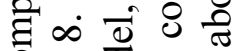

包氙完

¿ 0 D

Ð

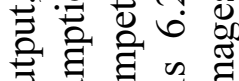

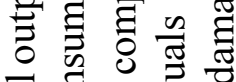

퓽 ठ0

फ.ヨ.

으-

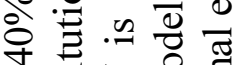

.

on $\overrightarrow{7}$ 늡

:

它.

记㻤

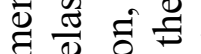

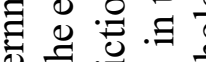

¿

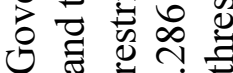




\section{References}

Asch, P., and J.J. Seneca, 1976, Monopoly and External Costs: An Application of Second-Best Theory to the Automobile Industry, Journal of Environmental Economics and Management 3: 6979.

Barnett, A.H., 1980, The Pigouvian Tax Rule under Monopoly, American Economic Review 70: 1037-1041.

Beccarello, M., 1996, Time Series Analysis of Market Power: Evidence from G-7 Manufacturing, International Journal of Industrial Organization 15: 123-136.

Bovenberg, A.L., and R. de Mooij, 1994, Environmental Levies and Distortionary Taxation, American Economic Review 94: 1085-1089.

Bovenberg, A.L., and L. Goulder, 2001, Neutralizing the Adverse Industry Impacts of Co2 Abatement Policies: What Does It Cost?, in: C. Carraro, and G.E. Metcalf, eds., Distributional and Behavioral Effects of Environmental Policy (University of Chicago Press, Chicago) 45-85.

Bovenberg, A.L., and L.H. Goulder, 1996, Optimal Environmental Taxation in the Presence of Other Taxes: General Equilibrium Analyses, American Economic Review 86: 985-1000.

Browning, E.K., 1987, On the Marginal Welfare Cost of Taxation, American Economic Review 77: 11-23.

Browning, E.K., 1994, The Non-Tax Wedge, Journal of Public Economics 53: 419-433.

Browning, E.K., 1997, A Neglected Welfare Cost of Monopoly--and Most Other Product Market Distortions, Journal of Public Economics 66: 127-144.

Buchanan, J.M., 1969, External Diseconomies, Corrective Taxes, and Market Structure, American Economic Review 59: 174-177.

Carraro, C., Y. Katsoulacos, and A. Xepapadeas, eds., 1996 (Kluwer Academic Publishers, Dordrecht).

Considine, T.J., 2001, Markup Pricing in Petroleum Refining: A Multiproduct Framework, International Journal of Industrial Organization 19: 1499-1526.

Domowitz, I., R.G. Hubbard, and B.C. Peterson, 1988, Market Structure and Cyclical Fluctuations in U.S. Manufacturing, Review of Economics and Statistics 70: 55-66.

Energy Information Administration, 2001, Emissions of Greenhouse Gases in the United States 2000, Washington, DC: U.S. Department of Energy.

Feldstein, M., 1995, The Effect of Marginal Tax Rates on Taxable Income: A Panel Study of the 1986 Tax Reform Act, Journal of Political Economy 103: 551-572. 
Fialka, J.J., 2000, Energy Secretary Says He Has Evidence Some Utilities Use Monopoly Power, New York Times, A4.

Freeman, A.M., 1982, Air and Water Pollution Control: A Benefit-Cost Assessment (John Wiley and Sons, New York).

Freeman, A.M., 2002, Environmental Policy since Earth Day I: What Have We Gained?, Journal of Economic Perspectives 16: 125-146.

Fuchs, V.R., A.B. Krueger, and J.M. Poterba, 1998, Economists' Views About Parameters, Values, and Policies: Survey Results in Labor and Public Economics, Journal of Economic Literature 36: 1387-1425.

Fullerton, D., and G.E. Metcalf, 1997, Environmental Controls, Scarcity Rents, and Pre-Existing Distortions, Cambridge, MA: NBER.

Fullerton, D., and G.E. Metcalf, 2001, Environmental Controls, Scarcity Rents, and Pre-Existing Distortions, Journal of Public Economics 80: 249-267.

Goulder, L.H., I. Parry, and D. Burtraw, 1997, Revenue-Raising Vs. Other Approaches to Environmental Protection: The Critical Significance of Pre-Existing Tax Distortions, RAND Journal of Economics 28: 708-731.

Hall, R.E., 1986, Market Structure and Macroeconomic Fluctuations, Brookings Papers on Economic Activity: 285-322.

Katsoulacos, Y., and A. Xepapadeas, 1995, Environmental Policy under Oligopoly with Endogenous Market Structure, Scandinavian Journal of Economics 97: 411-420.

Misiolek, W.S., 1980, Effluent Taxation in Monopoly Markets, Journal of Environmental Economics and Management 7: 103-107.

Nordhaus, W.D., 1991, To Slow or Not to Slow: The Economics of the Greenhouse Effect, The Economic Journal 101: 920-937.

Oates, W.E., and D.L. Strassmann, 1984, Effluent Fees and Market Structure, Journal of Public Economics 24: 29-46.

Office of Policy, 2000, Horizontal Market Power in Restructured Electricity Markets, Washington, DC: Office of Economic, Electricity and Natural Gas Analysis, U.S. Department of Energy.

Parry, I.W.H., 1995, Pollution Taxes and Revenue Recycling, Journal of Environmental Economics and Management 29: S64-S77.

Parry, I.W.H., 1997, Environmental Taxes and Quotas in the Presence of Distorting Taxes in 
Factor Markets, Resource and Energy Economics 19: 203-220.

Parry, I.W.H., R.C. Williams, III, and L.H. Goulder, 1999, When Can Carbon Abatement Policies Increase Welfare? The Fundamental Role of Distorted Factor Markets, Journal of Environmental Economics and Management 37: 52-84.

Pearce, D., and R.K. Turner, 1990, Economics of Natural Resources and the Environment (Johns Hopkins Press, Baltimore).

Pigou, A.C., 1932, The Economics of Welfare (MacMillan and Co., London).

Rosen, H., 1980, What Is Labor Supply and Do Taxes Affect It?, American Economic Review 70: 171-176.

Russek, F.S., 1996, Labor Supply and Taxes, Washington, DC: Congressional Budget Office.

Schmalensee, R., P.L. Joskow, A.D. Ellerman, J.P. Montero, and E.M. Bailey, 1998, An Interim Evaluation of Sulfur Dioxide Emissions Trading, Journal of Economic Perspectives 12: 53-68.

Stuart, C., 1984, Welfare Costs Per Dollar of Additional Tax Revenues in the United States, American Economic Review 74: 352-362.

U.S. Bureau of the Census, 1999, Statistical Abstract of the United States: 1999 (U.S. Government Printing Office, Washington, DC).

U.S. Environmental Protection Agency, 1997, The Benefits and Costs of the Clean Air Act: 19701990, Washington, DC.

U.S. Environmental Protection Agency, 2000, Allowance Prices,: U.S. EPA.

Wicke, L., 1990, Environmental Damage Balance Sheets, in: N. Akerman, ed., Maintaining a Satisfactory Environment: An Agenda for International Environmental Policy (Westview Press, Boulder CO). 